\title{
Perception of Leisure Agricultural Tourism Image Based on Wed Text Analysis: Case of Yearning Tea Plantation
}

\author{
Mufeng Chen ${ }^{1}$ \\ ${ }^{1}$ Department of Applied Foreign Languages, Guangdong Polytechnic, Foshan, Guangdong, China
}

\begin{abstract}
With the in-depth development of online tourism platforms, the online review of products in scenic spots has become an important basis for tourism consumption decisions. Through data mining and analysis of the online review of products in scenic spots, the tourism image perceived by tourists has become an important way to study the tourism image of scenic spots. Taking the Yearning Tea Plantation as an example, the word frequency and the content of tourism image attributes were analyzed by using the ROST CM6 content mining system software to comment on the online tourism platform for the sample of tourists, to understand the tourists' perception of the tourism image of the Yearning Tea Plantation, and to provide the basis for the improvement and improvement of the tourism image of the leisure agriculture scenic spot.
\end{abstract}

\section{1 statement of problem}

The Central Document No.1 of 2019 emphasizes that strengthening planning guidance and supporting the integrated development of leisure agriculture and rural tourism through a variety of effective methods. Since 2016 , the Central Document No. 1 has proposed "vigorously develop leisure agriculture and rural tourism". In recent years, with the continuous increase of national support for the integration of leisure agriculture and rural tourism, in the context of the sustained and rapid development of the national tourism industry, China's leisure agriculture and rural tourism have developed vigorously, from 720 million people in 2012 to 2017 Annual 2.8 billion person-times. In 2017, the revenue of leisure agriculture and rural tourism reached 740 billion yuan. Leisure agriculture has become an important engine of rural economic revitalization and a key link for the integration and development of rural industries.

Behind the rapid development, there are also some urgent problems in the development of leisure agriculture in China. Many leisure agricultural tourism stays on the appearance of sightseeing and picking, and the problem of assimilation is very prominent, the local characteristics are not enough, the tourism service facilities are not perfect, the lack of local cultural heritage and scientific planning and many other issues have affected tourists' perceived quality leads to a decrease in tourist satisfaction and revisit rates, which limits the depth and sustainable development of leisure agriculture.

With the deepening impact of "internet + " on the development of all walks of life, the tourism e-commerce industry is developing rapidly, and travel consumers, especially self-driving tourists, are more likely to experience the changes and benefits brought by "Internet
+". According to statistics, nearly two-thirds of tourists think it is more cost-effective to book travel products directly through online travel platforms. More than $60 \%$ of tourists will view product reviews on online travel platforms as an important basis for travel consumption decisions.

Therefore, this study analyzes the comments of travel consumers on the major online travel platforms, and explores the perception information of tourism consumers on the image of leisure agricultural tourism, providing a reference for the improvement and improvement of the tourism image of leisure agricultural tourism areas.

\section{The selection of research objects and research methods}

\subsection{Selection of research objects}

Yearning Tea Plantation is located in Meizhou, Guangdong, covering an area of 4.50 square kilometers. It integrates Hakka culture, tea culture and ecological culture. It is a tourist demonstration site, and won the highest award of China's construction engineering, "Luban Award", the National Three-High Agricultural Standardization Demonstration Zone, and the National Youth Civilization. In recent years, it has received more than 1 million tourists annually, paid more than 4 million yuan in taxes, and directly solved the employment of nearly 400 people. It has achieved obvious economic, social and ecological benefits, and has become the most beautiful tourism in East Guangdong. business card. Due to the early development of Yearning Tea Plantation, after more than 20 years of development, the brand image of "Yearning, tea love" has been recognized by domestic and foreign markets and has a high reputation and reputation 
in the country and even Southeast Asia. Degree, based on a larger number of sales and reviews in the online travel platform, analysis of the review text after tourists' consumption, to obtain the tourists' perception of Yearning Tea Plantation's real tourism image, and to improve and enhance the image of leisure agricultural tourism It has reference value, so Yearning Tea Plantation is selected as the research object.

\subsection{The research methods}

Tourism image is one of the most critical factors for attracting tourists. The comprehensive experience perception and emotional evaluation of tourists in attractions, tourist reception services, scenic nature and social environment constitute the overall content of tourist image. ${ }^{[1]}$ The review text after tourists' consumption is exactly the tourists' perception of Yearning Tea Plantation's real tourist image perception. In this study, ROST CM6 content mining system software developed by Professor Shen Yang was used to objectively, systematically and quantitatively analyze network text such as word segmentation, word frequency statistics and emotional tendency, so as to roughly present the tourist perception image of Yearning Tea Plantation. As a typical analysis, discuss the improvement and sustainable development of tourism image of leisure agricultural scenic spots.

Data source: Select the five influential travel websites such as Ctrip, Tongcheng, Qunar and Mafengwo Travel Network to collect text data, enter "Yearning Tea Plantation" as the keyword on the website, and select tourists in January 2014 By January 2019, the comments on the scenic spots have been sorted out to delete the system's default reviews and comments that have nothing to do with the scenic spots. "Self-driving tour" was combined and replaced with "Self-driving tour". Finally, a total of 787 useful reviews were collected.

\section{Image Perception Analysis of Leisure Agriculture Tourism Based on Web Text Analysis}

\subsection{High Frequency Vocabulary Analysis of tourism image of Yearning Tea Plantation}

ROST CM6 software is used to perform word frequency analysis on network texts, including "Yearning", "Qiaoxi ancient rhyme", "Round-Dragon House" and "Yearning Lake" into the custom dictionary. Word frequency statistics. From the high-frequency vocabulary of tourists' reviews, we can get a general understanding of tourists' perceptions and attitudes towards Yearning Tea Plantation tourism image. Most tourists give a high rating to the environment and air of Yearning Tea Plantation. Yearning Tea Plantation has fresh air and beautiful scenery, which is worth a visit. As the demand for rural cultural experience tourism grows, "Qiaoxi Ancient Rhyme" is close to Yearning Tea Plantation Resort, and most tourists take two scenic spots in series.
However, in addition to the tourists' favorable comments on the environment and air quality of the scenic area, tourists feel that the "Round-Dragon House" in the scenic area embodies the "Meizhou" and "Hakka" culture and is a major "characteristic" of the resort, but because of the remote location of the scenic area The resort has a large area and is suitable for "self-driving tours". There are also many tourists who think that the scenic spot is "less equipped" and "normal", and the "ticket" is evaluated as "too expensive, not worthwhile, and expensive".

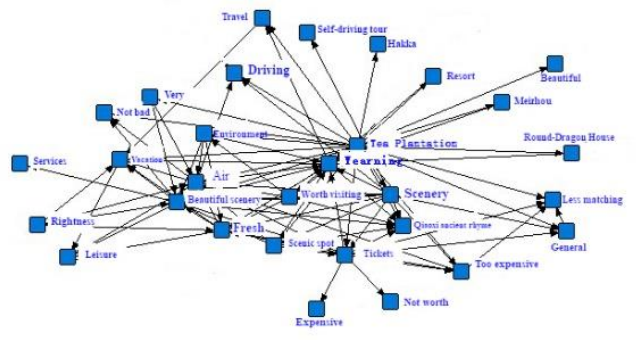

Fig1. HIGH FREQUENCY SEMANTIC GRAPH

\subsection{Content Analysis of Yearning Tea Plantation's Tourism Image Attribute}

The establishment of an analysis category is a prerequisite for the analysis of the content of tourism image attributes. Based on the high-frequency words obtained by ROST CM6 for tourist reviews, the actual situation of Yearning Tea Plantation and the comments of tourists are synthesized to construct a tourist attraction, tourist environment, and tourism. ${ }^{[4]}$ The content analysis category of tourism image attributes composed of 4 main categories of facilities and tourism services and 9 sub-categories.

\subsection{Coding reliability test}

In order to ensure the validity and significance of the content analysis of the image attributes of the text, after training the two coders, the internal reliability between the coders was checked. In this paper, the reliability of crossdiscrimination between different coders is tested to check whether the reliability of the classification results of each coder is consistent. Cross-discrimination reliability above 0.80 is acceptable, and above 0.90 is a good level. ${ }^{[3]}$

Calculating formula of reliability of interactive discrimination between coders:

$$
R=\frac{n \times K}{1+(n-1) K}
$$

In the formula, $\mathrm{R}$ is the reliability of interactive discrimination, $\mathrm{N}$ is the number of coders, and $\mathrm{K}$ is the average mutual agreement among coders. The calculation formula of the average mutual agreement $\mathrm{K}$ of two coders:

$$
K=\frac{2 M_{A B}}{N_{\mathrm{A}}+N_{B}}
$$

Among them, it is the number of analysis units with the same coding result by two coders, the number of analysis units coded by coder $\mathrm{A}$, and the number of analysis units coded by coder B. The discriminant value of 
the main category and sub-category of this study is greater than 0.90 , and the coding result has high reliability. ${ }^{[5]}$

\subsubsection{Content Analysis of Yearning Tea Plantation's Tourism Image Attribute}

From the perspective of the tourism image attribute content composed of 4 main categories and 9 subcategories, tourists' perception of the tourism image of Yearning Tea Plantation holiday village mainly focuses on the natural landscape in the tourist attraction and the consumption level in the environmental atmosphere.

In terms of tourist attractions, tourists' image perception of Yearning Tea Plantation is highly concentrated in the scenic tea fields, tea mountains, large fields of tea fields, and the fragrance of camellia flowers, which also reflects the "Yearning, Tea Love" brand image.

Tourists' consumption in the scenic area is affected by factors such as the lack of supporting facilities in the scenic area and the single attraction of the scenic area. ${ }^{[2]}$ Tourists generally believe that the tickets for the scenic area are too expensive, which is inconsistent with the identity of the $5 \mathrm{~A}$ scenic area.

Table1. Frequency statistics of tourism image attributes

\begin{tabular}{|c|c|c|}
\hline $\begin{array}{c}\text { Main } \\
\text { categories }\end{array}$ & $\begin{array}{c}\text { Sub- } \\
\text { categories }\end{array}$ & High-frequency words \\
\hline \multirow[t]{2}{*}{$\begin{array}{c}\text { Tourist } \\
\text { attraction }\end{array}$} & $\begin{array}{l}\text { Natural } \\
\text { landscape }\end{array}$ & $\begin{array}{c}\text { Tea Plantation(252), Beautiful scenery(221), } \\
\text { Worth visiting(77), Scenery(39), } \\
\text { Beautiful(32), Agriculture(24), Tea } \\
\text { plant(18), Green(18), Camellia(14), } \\
\text { Farmland(12), Yearning Lake(12), } \\
\text { Nature(11), Tea mountain(10) }\end{array}$ \\
\hline & $\begin{array}{l}\text { Cultural } \\
\text { landscape }\end{array}$ & $\begin{array}{l}\text { Qiaoxi ancient } \\
\text { rhyme(72),Hakka(47), Round-Dragon } \\
\text { House(34),Building(23), } \\
\text { Performance(16), Tea culture(14) }\end{array}$ \\
\hline \multirow[b]{2}{*}{$\begin{array}{l}\text { Environmen } \\
\text { tal climate }\end{array}$} & Air quality & $\begin{array}{l}\text { Air(226),Fresh(158), Natural } \quad \text { Oxygen } \\
\text { Bar(25), } \\
\text { Anion(11) }\end{array}$ \\
\hline & $\begin{array}{l}\text { Consumption } \\
\text { level }\end{array}$ & $\begin{array}{l}\text { Tickets(135), Too expensive(60), } \\
\text { Not worth(37),Expensive(35),Free(31), } \\
\text { Cost effective(26), } \\
\text { Price(16),Ticket price(12) }\end{array}$ \\
\hline \multirow{3}{*}{$\begin{array}{c}\text { Tourist } \\
\text { facilities } \\
\text { and services }\end{array}$} & $\begin{array}{l}\text { Transportatio } \\
\mathrm{n} \text { facilities } \\
\text { and services }\end{array}$ & $\begin{array}{l}\text { Driving(57), Go in(37), } \\
\text { Self-driving tour(33), Transportation(13), } \\
\text { Electromobile(10) }\end{array}$ \\
\hline & $\begin{array}{l}\text { Accommodat } \\
\text { ion and } \\
\text { services }\end{array}$ & $\begin{array}{l}\text { Hotel(26), Tasting tea(23),Dine(23), } \\
\text { The grand hotel(13), } \\
\text { Drink tea (12),Organic(12),Taste(10) }\end{array}$ \\
\hline & $\begin{array}{l}\text { Entertainmen } \\
\text { t Facilities } \\
\text { and Services }\end{array}$ & $\begin{array}{l}\text { Less matching(67),Playful(20), } \\
\text { Nothing(19),Fun(16),Tour(10) }\end{array}$ \\
\hline \multirow{2}{*}{$\begin{array}{l}\text { Scenic spot } \\
\text { management }\end{array}$} & $\begin{array}{c}\text { Scenic spot } \\
\text { management }\end{array}$ & $\begin{array}{l}\text { Services(50), Road sign(19), Attitude(17), } \\
\text { Clean(12) }\end{array}$ \\
\hline & $\begin{array}{c}\text { Scenic spot } \\
\text { development }\end{array}$ & $\begin{array}{l}\text { General scenic spot(77), General(28), } \\
\text { Not much(19),Only(16) }\end{array}$ \\
\hline
\end{tabular}

\subsection{Analysis of Emotional Image of Yearning Tea Plantation}

Tourists' emotional reactions or evaluations of destinations directly reflect tourists' perceptions of the destination's emotional image, mainly through the tourists' expressions of personal emotions. Using ROST CM6 software for sentiment analysis of online texts, tourists' positive sentiment to Yearning Tea Plantation Resort was
$76 \%$, neutral sentiment was $7 \%$, and negative sentiment was $17 \%$. Among them, tourists have the highest perception of the "scenic" "tea fields" and "fresh" "air", suitable for leisure and vacation, and "worthy of a visit", reflecting the tourists' love for Yearning Tea Plantation Resort. The "too expensive", "not worth", "less supporting", "nothing", "fun", "common scenic spots", etc. embodies the negative emotions of tourists, mainly concentrated in scenic spots tickets and tourism supporting facilities.

Table2. Analysis of Emotional Image of Yearning Tea Plantation

\begin{tabular}{|l|l|l|l|c|c|}
\hline $\begin{array}{l}\text { Emotional } \\
\text { categories }\end{array}$ & $\begin{array}{c}\text { Number } \\
\text { of words }\end{array}$ & Proportion & strength & $\begin{array}{c}\text { Number } \\
\text { of words }\end{array}$ & Proportion \\
\hline \multirow{2}{*}{$\begin{array}{l}\text { Positive } \\
\text { emotions }\end{array}$} & 597 & \multirow{2}{*}{76} & Normal & 235 & 30 \\
\cline { 4 - 6 } & & Moderate & 213 & 27 \\
\cline { 4 - 6 } $\begin{array}{l}\text { Neutral } \\
\text { emotions }\end{array}$ & 58 & 7 & High & 149 & 19 \\
\hline \multirow{2}{*}{$\begin{array}{l}\text { Negative } \\
\text { emotions }\end{array}$} & 132 & \multirow{2}{*}{17} & & & \\
\hline \multirow{2}{*}{ Total } & 787 & 100 & Moderate & 35 & 5 \\
\cline { 4 - 6 } & & & High & 0 & \\
\hline
\end{tabular}

\section{Conclusions and Suggestions}

\subsection{The research conclusion}

The above comprehensive analysis of the highfrequency words, image attribute content and emotional image of Yearning Tea Plantation's online reviews reflects the tourists' perception of Yearning Tea Plantation's overall image. Yearning Tea Plantation are characterized by beautifully landscaped tea fields, coupled with excellent air quality, tourists' perception of the overall image of Yearning Tea Plantation is mainly positive. However, apart from tea performances and Hakka singing and dancing performances in the Wailong Restaurant, there are few more projects that can allow tourists to participate and experience, and because there are relatively few tourist facilities in the scenic area, the attractions are scattered, and the cultural experience. The project is singular and insufficient, so it is generally believed that the scenic spot tickets are overpriced and have a certain negative emotion for Yearning Tea Plantation.

\subsection{Suggestions on Improving the Tourism Image of Yearning Tea Plantation}

\subsubsection{Develop more cultural experience projects to enrich the connotation of scenic tourism image}

The foundation of leisure agricultural tourism is agriculture, but in the process of developing leisure agricultural tourism, we must take "experience" as the main line and innovate the form of leisure agriculture to meet the higher consumer demand for experiential tourism consumption. Although Yearning Tea Plantation Resort has tea culture experience projects such as "tea tasting", it has a single form, low level 
and poor attractiveness, which makes it difficult to meet tourists' "experience" needs for leisure agriculture. Yearning Tea Plantation should give full play to the wisdom and role of tea farmers and "Qiaoxi ancient rhyme" rural farmers, let tea farmers and farmers participate in the design and development of scenic spot experience projects, and enrich the tourism image of Yearning Tea Plantation.

\subsubsection{Increase efforts to improve tourism supporting facilities in scenic spots}

Yearning Tea Plantation has a single tourist attraction and few supporting facilities, so that many tourists feel that "nothing is fun." In terms of tourism supporting facilities and services, Yearning Tea Plantation has invested 120 million yuan in 2017 to improve the function of the scenic spot, but it mainly focuses on infrastructure such as "repairing the road, rebuilding the tea court, and building three toilet complexes." Judging from the online reviews of Yearning Tea Plantation Resort in the past two years, tourists have not changed much. Yearning Tea Plantation Resort must pay attention to tourists' demand for transportation facilities and entertainment facilities, increase investment and accelerate construction.

\subsubsection{Actively promote the transformation from "scenic tourism" to "global tourism"}

Global tourism is the overall strategy of China's tourism development in the new era. As can be seen from the highfrequency vocabulary network map, tourists generally choose to play the "Qiaoxi Ancient Rhyme" together when traveling to Yearning Tea Plantation Scenic Spot, but most tourists feel that the two scenic spots have too high tickets and inconvenient transportation. "Qiaoxi Ancient Rhyme" is also invested, developed and operated by Yearning Tea Plantation. Under the development trend of global tourism, Yearning Tea Plantation Scenic Area and "Qiaoxi Ancient Rhyme" Scenic Area should be designed in series, with a single ticket set and arranged the free shuttle bus provides tourists with a tour service to reduce the negative emotions of tourists on the tourism image of leisure agricultural scenic spots brought by the overlapping of tickets and their single scenery.

\section{REFERENCES}

1. MIAO Hong, MA Jin-tao, ZHANG Huan, "Research on Leisure Agricultural Development and Demand characteristics in NIingxia- Based on the Content Analysis of Network Text," Research on Development, vol. 2, pp.104-108,2014. (In Chinese)

2. Holsti O. R, Content Analysis for The Social Sciences and Humanities [M] .MA: Addison-Wesley,1969: 138-141.

3. DING Xin, WANG Jing-qiang, WANG Xiao-yan, "Wuyi Impression: Study on Tourist Destination Image Perception Based on Network Text Analysis," Resource Development \& Market, vol. 1, pp.127132,2019. (In Chinese)
4. Lee S., Scott D., Kim H.Celebrity fan involvement and destination per-ceptions[J].Annals of Tourism Research, 2008, 35 (3) :809-832.

5. Gallarza M.G., Gill I.S., Calderón H.G. Destination image:Towardsa conceptual framework[J].Annals of Tourism Research, 2002, 29 (1) :56-78. 